Document downloaded from:

http://hdl.handle.net/10251/63317

This paper must be cited as:

Sanchis Jiménez, EM.; Ferrer Roglán, M.; Calvet Sanz, S.; C. Coscollà; V. Yusà; Cambra López, M. (2014). Gaseous and particulate emission profiles during controlled rice straw burning. Atmospheric Environment. 98:25-31. doi:10.1016/j.atmosenv.2014.07.062.

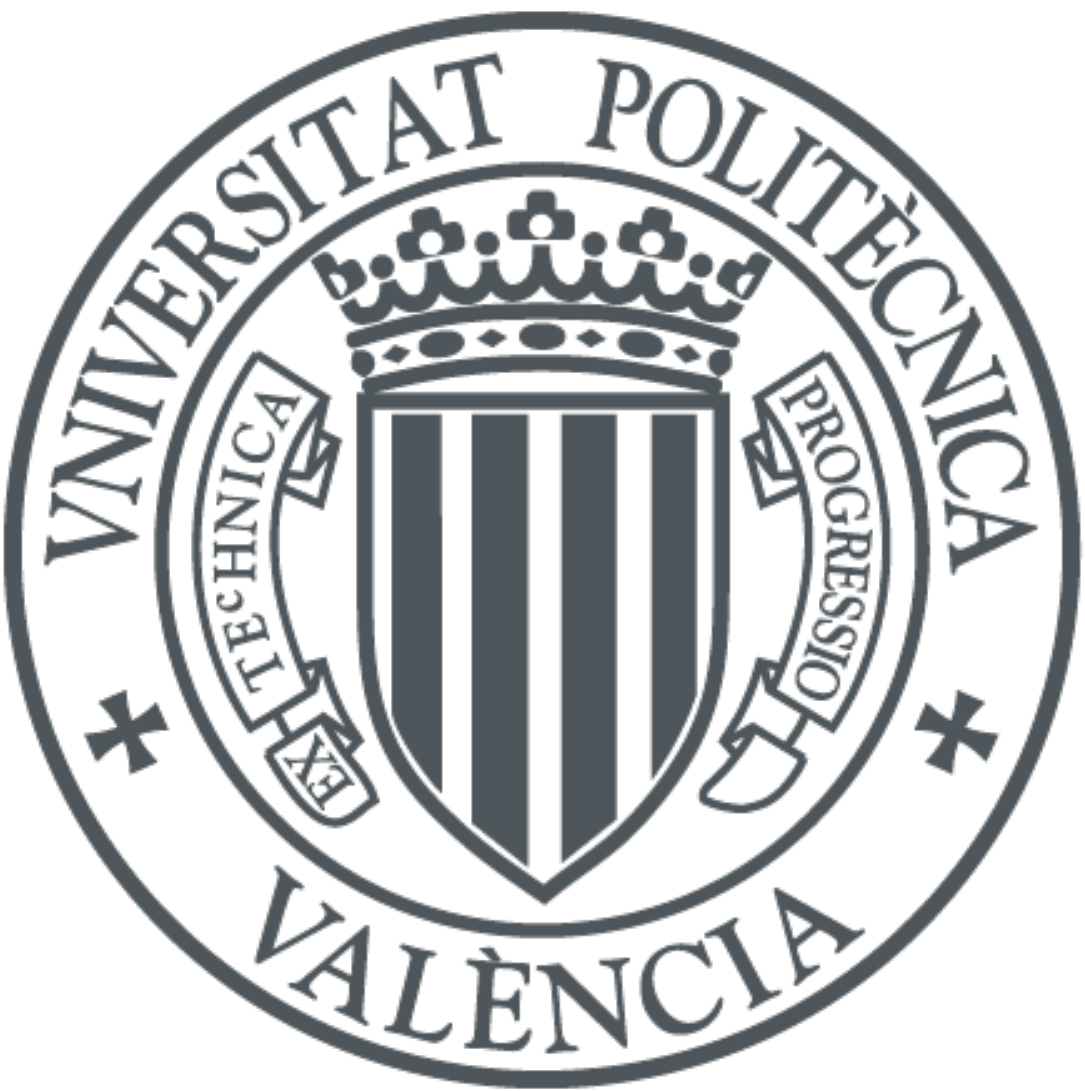

The final publication is available at

http://dx.doi.org/10.1016/j.atmosenv.2014.07.062

Copyright Pergamon Elsevier

Additional Information 


\section{Gaseous and particulate emission profiles during controlled rice straw burning}

Sanchis, $E^{1}$., Ferrer, $M^{1}$., Calvet, $S^{1}$., Coscollà, $C^{2}$., Yusà, V²., Cambra-López, $M^{1}$.

${ }^{1}$ Institute of Animal Science and Technology, Universitat Politècnica de València. Camino de Vera s.n. Valencia, Spain.

${ }^{2}$ Centre for Public Health Research (CSISP-FISABIO), 21 Avenida Catalunya, 46020 Valencia, Spain.

Corresponding author: María Cambra-López, ${ }^{1}$ Institute of Animal Science and Technology, Universitat Politècnica de València. Camino de Vera s.n. Valencia, Spain. T. +34 9638779885, F. +34963877439, email. macamlo@upvnet.upv.es.

\section{Abstract}

Burning of rice straw can emit considerable amounts of atmospheric pollutants. We evaluated the effect of rice straw moisture content $(5 \%, 10 \%$ and $20 \%)$ on the emission of carbon dioxide $\left(\mathrm{CO}_{2}\right)$ and on the organic and inorganic constituents of released particulate matter (PM): dioxins, heavy metals, and polycyclic aromatic hydrocarbons (PAHs). Four burning tests were conducted per moisture treatment using the open chamber method. Gaseous emission profiles of carbon monoxide (CO), sulfur dioxide $\left(\mathrm{SO}_{2}\right)$, nitrogen monoxide $(\mathrm{NO})$, and nitrogen dioxide $\left(\mathrm{NO}_{2}\right)$ were also measured. Additionally, combustion characteristics, including burning stages, durations, combustion efficiency, temperature, and relative humidity, were recorded. Burning tests showed flaming and smoldering stages were significantly longer in $20 \%$ moisture treatment $(\mathrm{P}<0.05)$ compared with the rest. The amount of burned straw and ashes decreased with increasing straw moisture content $(\mathrm{P}<0.001)$. Carbon dioxide was the main product obtained during combustion with emission values ranging from $692 \mathrm{~g} \mathrm{CO}_{2} \mathrm{~kg}_{\text {dry straw }}{ }^{-1}$ (10\% moisture content) to $835 \mathrm{~g} \mathrm{CO}_{2}$ $\mathrm{kg}$ dry $\operatorname{straw}^{-1}$ (20\% moisture content). Emission factors for PM were the highest in $20 \%$ moisture treatment $(\mathrm{P}<0.005)$. Fine PM (PM2.5) accounted to more than $60 \%$ of total PM mass. Emission factors for dioxins increased with straw moisture content, being the highest in $20 \%$ moisture treatment, although showing a wide variability among burning tests $(\mathrm{P}>0.05)$. Emissions factors for heavy metals were low and similar among moisture treatments $(\mathrm{P}>0.05)$. Emission factors for individual PAHs were generally higher in $20 \%$ moisture treatment. Average $\mathrm{SO}_{2}$ and $\mathrm{NO}$ emissions decreased with moisture content. In contrast, $\mathrm{CO}$ emissions increased with moisture content. Overall, emission factors of atmospheric pollutants measured in our study were higher in the $20 \%$ moisture content. This difference could be attributed to the incomplete combustion at higher levels 
of rice straw moisture content. According to our results, rice straw burning should be done after straw drying and under minimal moisture conditions to lower pollutant emission levels.

Keywords: biomass burning, moisture content, greenhouse gas, particulate matter, organic pollutants. 


\section{Introduction}

Rice cultivation covers large areas of South-Eastern Asian countries (mainly China, India, Thailand and Philippines) and localized regions of Spain, Italy, and North America. Post-harvesting field burning is still a common practice to remove straw cereals in many of these countries (Gadde et al., 2009). Burning rice straw poses benefits for the farmer since it controls weeds and reduces crop diseases, prepares the field for the next harvest and releases nutrients for the following crop (Cheng et al., 2009, Gadde et al., 2009, Kadam et al., 2000, Lemieux et al., 2004). Rice straw burning, however, can contribute to impairing local air pollution, causing severe impacts on human health (Gullett and Touati, 2003, Hays et al., 2005, Lin et al., 2007), particularly bronchial asthma (Arai et al., 1998, Torigoe et al., 2000).

Rice straw burning can emit considerable amounts of atmospheric pollutants, mainly carbon dioxide $\left(\mathrm{CO}_{2}\right)$ and particulate matter (PM). Other pollutants are also emitted during rice straw burning: carbon monoxide $(\mathrm{CO})$, methane $\left(\mathrm{CH}_{4}\right)$, nitrogen oxides $\left(\mathrm{NO}_{\mathrm{x}}\right)$, sulfur oxides $\left(\mathrm{SO}_{\mathrm{x}}\right)$, nonmethane hydrocarbons (NMHC), and some organic and inorganic compounds such as heavy metals, ions, volatile organic compounds (VOCs), dioxins (polychlorinated dibenzo-p-dioxins and dibenzofurans (PCDD/Fs)), and polycyclic aromatic hydrocarbons (PAHs), which are emitted in gas phase or as constituents of the PM (Andreae and Merlet, 2001, Cheng et al., 2009, Gadde et al., 2009, Hays et al., 2005, Lemieux et al., 2004, Zhang et al., 2008). Although some of these air pollutants such as PAHs or PCDD/Fs are released at low concentrations, they have harmful toxicological properties (Lemieux et al., 2004, Shih et al., 2008) and are potential carcinogens (Conde et al., 2005). Consequently, burning rice straw has been regulated and restricted in many regions worldwide despite its economic and practical benefits. For instance, in Spain, farmers continue to burn the straw and stubble that remains on the field after harvesting (Ortiz de Zárate et al., 2000).

Biomass burning includes two stages: flaming and smoldering; as well as a transitional state between them (Ogawa and Yoshida, 2005). During the flaming stage, the fuel mixture ignites, releasing mostly gases and soot particles (Andreae and Merlet, 2001). Once most volatiles have been released, the smoldering stage begins. The smoldering stage is a poor combustion phase, resulting from a low combustion temperature, insufficient mixing of fuel with combustion air, and a short residence time of the combustible gases in the combustion zone. Consequently, large amounts of incompletely oxidized pyrolysis products, such as CO, NMHC, ammonia, and the nitriles are released to the atmosphere (Andreae and Merlet, 2001, Khan et al., 2009). Khan et al. (2009) classified the pollutants emitted in a burning process into two classes: pollutants that are produced by combustion and unburned pollutants. Pollutants produced by combustion are emitted during the flaming stage, whereas unburned pollutants are usually produced in the smoldering stage. 
Rice growers need economically viable and environmentally sustainable ways to manage large amounts of residual rice straw. Thus, there is a strong need for assessing environmental and health impacts of rice straw burning. In this framework, accurate and reliable emission data on rice straw properties and burning conditions affecting physicochemical profiles of gaseous and particulate emissions are required to reduce atmospheric pollution. Atmospheric emissions largely depend on the fuel and on the physical and chemical processes during combustion (Andreae and Merlet, 2001). Conde et al. (2005) found that when temperature and CO concentration drop during the combustion process (indicative of a reductive combustion with lack of oxygen) the quantity of PAHs decreased considerably independent from the device used for burning. Moreover, moisture content of rice straw can affect PAH emissions during rice straw burning (Korenaga et al., 2001, Lu et al., 2009). However, data on the effect of rice straw moisture content on other pollutants different from PAHs is still limited.

The objective of this study was to evaluate the effect of rice straw moisture content $(5 \%, 10 \%$, and $20 \%$ ) during rice straw burning, on the emission of $\mathrm{CO}_{2}$ and on the organic and inorganic constituents of released PM. A detailed quantification of dioxins, heavy metals, and PAHs in PM was performed. Gaseous emission profiles of $\mathrm{CO}$, sulfur dioxide $\left(\mathrm{SO}_{2}\right)$, nitrogen monoxide (NO) and nitrogen dioxide $\left(\mathrm{NO}_{2}\right)$ were also measured. Combustion characteristics, including burning stages, durations, combustion efficiency, temperature, and relative humidity, were also characterized.

\section{Material and Methods}

2.1. Experimental design: Open chamber burn simulations

All tests were performed in an environmentally controlled chamber at the Institute of Animal Science and Technology of the Universitat Politècnica de València (Spain). The open chamber method was used (Miura and Kanno, 1997). Fig. 1 shows the distribution and dimensions of the environmentally controlled chamber.

The air inside the chamber was exhausted using a variable-speed wall fan (Exafan, Spain). The fan operated at a constant airflow rate of $2,856 \mathrm{~m}^{3} \mathrm{~h}^{-1}$, measured according to ASHRAE (2001) using a hot-wire anemometer (Model 425, Testo, Germany). Air was allowed to enter the chamber through 12 evenly distributed openings ( $0.6 \mathrm{~m}$ wide x $0.2 \mathrm{~m}$ high) located on the opposite sidewall. Air openings and airflow rate were established to simulate a wind speed over the straw surface ranging from 0.1 to $0.3 \mathrm{~m} \mathrm{~s}^{-1}$, which was confirmed using a hot-wire anemometer (Model 425, Testo, Germany).

Three moisture contents of rice straw were evaluated: 5\%, 10\%, and 20\% moisture. Moisture was achieved by sealing oven-dried straw (at $105^{\circ} \mathrm{C}$ until constant weight) with different volumes of 
distilled water in plastic bags, until water was completely absorbed. Four burning tests (repetitions) were conducted per moisture treatment. Overall, a total of 12 burning tests were performed.

In each test, three kilograms of rice straw (fresh mass) were weighed using a balance (KERN \& Sohn GmbH, Germany). Two parallel stacks were prepared on the chamber floor, simulating onfield burning conditions (Fig. 1). Ignition was performed from one end of the stack, closest to the window openings. This constituted the start of each test, which concluded when smoke production ended. In each test, the flaming and smoldering stages were identified and their durations were recorded. Smoldering stage started when the flame constituting the flaming stage disappeared. After each test, unburned straw and ashes were collected separately and weighed. The amount of effectively burned straw was calculated as the difference between the initial straw and the sum of ashes and unburned straw. Temperature and relative humidity of the air entering the chamber were measured every five seconds using a data-logger (HOBO U12 RH/Temp/Out, Onset Computer Corp., Pocasset, Mass, U.S.A.). All gas and PM concentrations measurements were conducted close to the exhaust fan, $1 \mathrm{~m}$ away from it, and at a height of 1.5-2 m (Fig. 1).

\subsection{Fuel characteristics}

Table 1 shows the initial physical-chemical composition of rice straw used in this study, before oven-drying and water addition.

Moisture content and ashes were determined by drying in the oven at $105^{\circ} \mathrm{C}$ and $550^{\circ} \mathrm{C}$ respectively, for $24 \mathrm{~h}$ according to AOAC International (AOAC International, 2003). Heating value was determined in an adiabatic bomb calorimeter (Gallenkamp Autobomb, Loughborough, U.K.) according to the ASTM D2015 standard method (ASTM, 2000). The carbon:nitrogen (C:N) ratio was determined using an elemental microanalyzer LECO CNS-2000I (Leco Corporation, U.S.A.).

\subsection{Sampling collection: gases and PM}

During each burning test, the concentration of $\mathrm{CO}_{2}$ was continuously measured with an infrared detector, NDIR (GMT-222, Vaisala, Helsinki, Finland), ranging from 0 to $10,000 \mathrm{ppm}$. The $\mathrm{CO}_{2}$ concentration was registered every five seconds using a data-logger (HOBO U12 RH/Temp/Out, Onset Computer Corp., Pocasset, Mass, U.S.A.).

Additionally, $\mathrm{CO}, \mathrm{SO}_{2}, \mathrm{NO}_{2}$ and $\mathrm{NO}$ concentrations were measured using colorimetric gas detection tubes (Gastec $\mathrm{n}^{\circ} 1 \mathrm{LK}, \mathrm{n}^{\circ} 5 \mathrm{LC}$ and $\mathrm{n}^{\circ} 10$, Gastec Corporation, Japan). Each gas was measured twice during each burning test: once during the flaming stage and another time during the smoldering stage. A gas sampling pump (Gastec GV-100S, Gastec Corporation, Japan) was used to pull $100 \mathrm{~mL}$ of air sample through the tube. The concentration was determined based on a color change in the tube media. 
Fine (PM2.5), coarse (PM10-2.5), and total suspended particles (TSP) concentrations generated during each burning test were collected using a virtual cascade impactor (RespiCon, Wetzlar, Germany). A portable pump (Genie VSS5, Buck Inc, U.S.A.) was used to suck air through the impactor at a constant flow of $3.11 \mathrm{~L} \mathrm{~min}^{-1}$. Particles were collected on quartz fiber filters of 37 mm of diameter (Dräger Safety Ag \& Co., Luebeck, Germany). Sampling time was set according to burning duration (from the start of the ignition until the smoke disappeared). Loaded filter samples were stabilized during 48 hours before analysis at room conditions (temperature $=20 \pm 1^{\circ} \mathrm{C}$ and relative humidity $=50 \pm 5 \%$ ). Filters were weighed before and after each sampling in a $10 \mu \mathrm{g}$ precision balance (Mettler Toledo MX5, Bedford, MA, U.S.A.) following EN 12341:1998 regulation (CEN, 1998).

An additional PM10 sample collected using a large-volume sampler from Digitel (Madrid, Spain) was used for analyzing particle-bound dioxins, heavy metals, and PAHs. Samples were collected in quartz fiber filters of $150 \mathrm{~mm}$ of diameter (Schleicher \& Schuell Microscience GmbH, Dassel, Germany). Two out of four PM10 samples used in each burning test per moisture treatment were divided into two parts using ceramic scissors for heavy metals and PAHs analysis, respectively. The other two PM10 samples were used for dioxin analysis.

\subsection{Analytical methods}

A total of nine PAHs were measured in straw and in particle-bound PM10: fluoranthene $\{\mathrm{Fla}\}$, benz(a)anthracene $\{\mathrm{B}(\mathrm{a}) \mathrm{A}\}$, benz(b)fluoranthene $\{\mathrm{B}(\mathrm{b}) \mathrm{F}\}$, benz(j)fluoranthene $\{\mathrm{B}(\mathrm{j}) \mathrm{F}\}$, benz $(k)$ fluoranthene $\{\mathrm{B}(\mathrm{k}) \mathrm{F}\}$, benz(a)pyrene $\{\mathrm{B}(\mathrm{a}) \mathrm{P}\}$, indene $(1,2,3-\mathrm{c}, \mathrm{d})$ pyrene $\{\mathrm{I}(1,2,3-\mathrm{c}, \mathrm{d}) \mathrm{P}\}$, $\operatorname{dibenz}(\mathrm{a}, \mathrm{h})$ antracene $\{\mathrm{D}(\mathrm{a}, \mathrm{h}) \mathrm{A}\}$, and benz $(\mathrm{g}, \mathrm{h}, \mathrm{i})$ perylene $\{\mathrm{B}(\mathrm{g}, \mathrm{h}, \mathrm{i}) \mathrm{Pe}\}$. Polychlorinated dibenzo-pdioxins, PCDD/Fs and heavy metals (cadmium $(\mathrm{Cd})$, lead $(\mathrm{Pb})$, arsenic (As) and nickel $(\mathrm{Ni})$ ) were also measured in this study in straw and PM10-bound.

For PAHs analysis, 4 grams of straw or half PM10 filter sample were weighed and spiked with 250 $\mu \mathrm{L}$ of a surrogate solution containing Pyrilene D10 (1000 $\left.\mathrm{ng} \mathrm{mL}^{-1}\right)$ and extracted by an accelerated solvent extraction system (ASE 200, Dionex, Sunnyvale, CA, U.S.A.) equipped with $22 \mathrm{~mL}$ stainless steel extraction cells. Sample extraction was performed using acetone-hexane $(1: 1, \mathrm{v} / \mathrm{v})$ solvent mixture. Samples were introduced in $22 \mathrm{~mL}$ stainless-steel cells containing a cellulose filter in the cell outlet, and the cell refilled with Hyflo Super Cell®. The extraction conditions were as follows: oven temperature, $125^{\circ} \mathrm{C}$; pressure, $1500 \mathrm{psi}$; 5-min heat-up time; two static cycles; static time, $5 \mathrm{~min}$. The flush volume amounted to $60 \%$ of the extraction cell volume. The extracted analytes were purged from the sample cell using pressurized nitrogen $\left(\mathrm{N}_{2}\right)$ (125-150 psi) for 1 minute. Afterwards, the extracts were concentrated under a gentle stream of $\mathrm{N}_{2}$ at $40^{\circ} \mathrm{C}$ and redissolved in $5 \mathrm{~mL}$ of dichloromethane. The Gel Permeation Chromatography Clean Up System (GPC clean-up) was used with an injection volume of 1:5 mL. The GPC was integrated by a 
Waters 515 high-pressure liquid chromatography pump, a Waters 717 sample input module, tandem columns Envirogel GPC clean-up 19mm $\times 150 \mathrm{~mm}$ and $19 \mathrm{~mm} \times 300 \mathrm{~mm}$, and a Waters 2487 UV detector $(254 \mathrm{~nm})$, together with a Gilson FC 204 Fraction Collector. To concentrate the extracts, a TurboVapII Concentration Workstation from Zymac (Hopkinton, MA, U.S.A.) was used. The collected fractions were evaporated under $\mathrm{N}_{2}$ flow at $40^{\circ} \mathrm{C}$, and re-dissolved in $1 \mathrm{~mL}$ of a solution containing Chrysene D12 and Perylene D12 (50 ng mL ${ }^{-1}$ in hexane) as internal standards, before being analyzed in a gas chromatograph-mass spectrometer (GC-MS). Chromatography was performed on a GC-MS from Agilent 6890 and mass spectrometer from Agilent 5973 (Wilmington, DE, U.S.A.). Separation was carried out on an Agilent DB-EUPAH, 20m x 0.180mm x 0,14cm capillary column. High-purity helium (99.999\%) was employed as carrier gas.

For the determination of dioxin compounds in straw and PM10 samples, extraction was performed using a hexane-acetone $(90: 10, \mathrm{v} / \mathrm{v})$ solvent mixture, in the same accelerated solvent extraction system as PAHs. Samples were introduced in $22 \mathrm{~mL}$ stainless-steel cells containing a cellulose filter in the cell outlet, and the cell refilled with Hyflo Super Cell®. The extraction conditions were as follows: oven temperature, $100{ }^{\circ} \mathrm{C}$; pressure, $2000 \mathrm{psi}$; 5-min heat-up time; three static cycles; static time, $5 \mathrm{~min}$. The flush volume amounted to $60 \%$ of the extraction cell volume. The extracted analytes were purged from the sample cell using pressurized nitrogen (125-150 psi) for $1 \mathrm{~min}$. Afterwards, the extracts were cleaned-up on a pre-conditioned silica column, which was filled with sulphuric acid silica gel. The PCDD/Fs were eluted and redisolved with $25 \mu \mathrm{L}$ of dimethylsulfoxide (DMSO). The target compounds were analyzed using the enhanced recombinant mouse hepatoma CALUX cell line (H1L7.5 cells) which had been stably transfected with an Ah receptor-responsive firely luciferase reporter gene plasmid (pGudLuc7.5) (He et al., 2011). The results were expressed as dioxin toxicity equivalents (TEQ).

The analytical quantitation of heavy metals in straw and PM10 samples was performed using inductively coupled plasma mass spectrometry (Perkin Elmer). A microwave laboratory system (Mars system from CEM corporation (Mathews, NC, U.S.A.)) was employed for sampling digestion. One $\mathrm{g}$ of straw or half PM10 filter sample were placed inside Teflon vessel and $8 \mathrm{~mL}$ of concentrated nitric acid was added. The system operated at a maximum exit power of $1000 \mathrm{~W}$.

2.5. Emission calculation and data analysis

Within the open chamber, emissions were calculated as the product of the ventilation flow in the chamber times the difference between outlet and inlet concentrations (outlet minus inlet) for each specific pollutant. According to preliminary tests, incoming pollutant concentrations were negligible compared to chamber outlet concentrations for all pollutants except for $\mathrm{CO}_{2}$. Therefore, incoming pollutant concentrations were only considered for $\mathrm{CO}_{2}$ emission calculation. Estellés et al. (2010) demonstrated that when ventilation is constant, the chamber method provides the same 
result when considering a series of punctual pollutant concentrations or concentration averages from this series. Therefore, although the mass of pollutants was expected to vary depending on the burning stage, average values of concentrations and ventilation rates were used to calculate pollutant emissions.

Results were expressed as the amount of pollutant released per amount of dry fuel consumed, which is also known as emission factor (EF). Units were grams, nanograms or picograms (depending on the pollutant) per kilograms of consumed fuel (Andreae and Merlet, 2001).

Andreae and Merlet (2001) reported that when EF is given relative to other fuel mass indicator, Equation 1 can be used to convert concentration data into EF.

$$
\mathrm{EF}_{\mathrm{X}}=\mathrm{ER}_{(\mathrm{X} / \mathrm{Y})} \cdot \frac{\mathrm{MW}_{\mathrm{X}}}{\mathrm{MW}_{\mathrm{Y}}} \cdot \mathrm{EF}_{\mathrm{Y}} \quad \text { (Equation 1) }
$$

where $\mathrm{ER}_{(\mathrm{X} / \mathrm{Y})}$ is the emission ratio of species $\mathrm{x}$ relative to the reference species $\mathrm{y}, \mathrm{MW}_{\mathrm{X}}$ and $\mathrm{MW}_{\mathrm{Y}}$ are the molecular weights of the species $\mathrm{x}$ and the reference species $\mathrm{y}$, and $\mathrm{EF}_{\mathrm{Y}}$ is the EF of the reference species. This equation was used to convert $\mathrm{CO}, \mathrm{SO}_{2}$, and $\mathrm{NOx}$ concentration values into $\mathrm{EF}$, relative to $\mathrm{CO}_{2}$.

Finally, combustion efficiency (CE) was calculated as the ratio of released carbon in the form of $\mathrm{CO}_{2}$ to the total mass of carbon released during combustion, according to Ward et al. (1992). However, as only $\mathrm{CO}_{2}$ and $\mathrm{CO}$ were measured, the modified combustion efficiency (MCE) was used following Equation 2 (Zhang et al., 2008). Equation 2 was used to characterize the completeness of the oxidation of released carbon during the combustion of biomass fuels (Sahai et al., 2007).

$$
\operatorname{MCE}(\%)=\frac{\mathrm{C}_{\left[\mathrm{CO}_{2}\right]}}{\mathrm{C}_{\left[\mathrm{CO}_{2}\right]}+\mathrm{C}_{[\mathrm{CO}]}} \cdot 100 \quad \text { (Equation 2) }
$$

where MCE is the modified combustion efficiency, $\mathrm{C}_{[\mathrm{CO} 2]}$ is the $\mathrm{CO}_{2}$ concentration and $\mathrm{C}_{[\mathrm{CO}]}$ is the CO concentration.

Statistical significant differences between moisture treatments for pollutant emissions and combustion characteristics were determined with one-way ANOVA using SAS software (SAS, 2009), with moisture content as the source of variance. Average values per burning test were the experimental units in the ANOVA analyses. Differences with $\mathrm{P}$ values less than 0.05 were considered to be statistically significant.

\section{Results and discussion}

\subsection{Combustion characteristics}

As regards environmental conditions during burning tests, ambient temperature of the air entering the chamber ranged from 18 to $20^{\circ} \mathrm{C}$. Relative humidity ranged from 37 to $54 \%$. Table 2 
summarizes combustion characteristics of each burning test per moisture treatment. Burning tests lasted between 19 and 34 minutes including flaming and smoldering. Burning duration was significantly longer in $20 \%$ moisture treatment $(\mathrm{P}<0.05)$ compared with the rest. This was mainly attributable to the flaming stage, which was about two-fold longer in $20 \%$ moisture treatment compared with other treatments. The smoldering stage ranged from 9.5 to $13 \mathrm{~min}$, being the longest in $10 \%$ moisture treatment.

The amount of burned straw and ashes decreased with increasing moisture content $(\mathrm{P}<0.001)$. Maximum burned straw was $76.5 \%$ of the initial straw mass $(\mathrm{kg} \mathrm{d.m.)} \mathrm{in} \mathrm{the} 5 \%$ moisture treatment. Unburned straw showed an opposite trend and its maximum (35.3\%) was in $20 \%$ moisture treatment. This could be due to incomplete combustion. In field conditions, unburned residues which remain in rice fields after burning are incorporated to the soil, increasing soil organic matter content. This increase, however, may enhance $\mathrm{CH}_{4}$ emissions (Sanchis et al., 2012). Our results suggest this could be especially relevant in field burning conditions of straw with high moisture content (e.g. $20 \%$ or higher).

Representative examples of burning stages and durations for the three treatments in terms of $\mathrm{CO}_{2}$ concentration over time are shown in Fig. 2. This figure outlines the differences in combustion processes among treatments and burning stages. In all cases, most $\mathrm{CO}_{2}$ was produced during the flaming stage. The $\mathrm{CO}_{2}$ concentration was the highest in $5 \%$ moisture treatment. Moreover, $\mathrm{CO}_{2}$ concentration peak was narrower and higher in 5\% moisture treatment than in the rest. Differences in $\mathrm{CO}_{2}$ concentration between stages were less evident in $20 \%$ moisture treatment, showing an irregular trend due to incomplete combustion. Consequently, the duration of flaming stage was the longest in $20 \%$ moisture treatment.

\subsection{Gaseous and particulate emissions factors}

Pollutants emitted during the burning of rice straw per moisture treatment are shown in Table 3. The main product obtained during the combustion process was $\mathrm{CO}_{2}$, with emission values ranging from 692 (10\% moisture content) to $835 \mathrm{~g} \mathrm{CO}_{2} \mathrm{~kg}$ dry straw $^{-1}$ (20\% moisture content). Average emissions of $\mathrm{CO}_{2}$ were similar $(\mathrm{P}>0.05)$ among moisture treatments. The $\mathrm{CO}_{2} \mathrm{EFs}$ reported in our study were similar to those found in Zhang et al. (2008) for rice straw. However, $\mathrm{CO}_{2}$ results were lower than the EFs reported in Ortiz de Zárate et al. (2000), Zhang et al. (2000) and Andreae and Merlet (2001) from diverse agricultural residues, and Sahai et al. (2007) for wheat straw.

Emission factors for PM (PM2.5, PM10-2.5, and TSP) were significantly higher in the $20 \%$ moisture treatment $(\mathrm{P}<0.005)$ compared with the rest of treatments. The PM2.5 fraction accounted to more than $60 \%$ of total PM mass. These results are in reasonable agreement with the values published in Cao et al. (2008), Ortiz de Zárate et al. (2000) and Andreae and Merlet (2001). Hays et al. (2005) reported differences in combustion-derived PM emission when burning rice and wheat 
straw residues. When burning rice residues, PM emission was largely carbonaceous; whereas when burning wheat residues, PM emissions were enriched in potassium $(\mathrm{K})$ and chlorine $(\mathrm{Cl})$.

Emission factors for dioxins (TEQ) increased with straw moisture, being the highest in 20\% moisture treatment, although showing a wide variability among burning tests $(\mathrm{P}>0.05)$. Gullett and Touati (2003) studied the emissions of PCDD/F from burning wheat and rice field residue in the United States of America and obtained higher EFs than those reported in this study. These differences could be explained by the impurities in herbicides and pest-control products used in paddy fields in different countries. Most of the PCDD/Fs contained in soil through herbicides application are transferred to the atmosphere during field burning of rice straw (Minomo et al., 2011).

Emissions factors for heavy metals were low and similar among moisture treatments $(\mathrm{P}>0.05)$. Emissions of heavy metals depend on their concentration in the fuel and the combustion temperature (Lemieux et al., 2004). Therefore, their presence during rice burning could be a consequence of the bioaccumulation of trace metals is rice straw (Viana et al., 2008) and presumably would not be significantly affected by straw moisture content.

Emission factors for individual PAHs were generally higher in $20 \%$ moisture content with differences among individual PAHs (Table 3). The sum of EFs of nine PAHs was $3.02 \mu \mathrm{g} \mathrm{kg}^{-1}$ (5\% moisture content), $8.32 \mu \mathrm{g} / \mathrm{kg}$ (10\% moisture content) and $17.1 \mu \mathrm{g} / \mathrm{kg}(20 \%$ moisture content) (data not shown). Moisture content has a positive effect on the emission of PAHs, since PAHs are products of incomplete combustion (Conde et al., 2005, Dhammapala et al., 2007). These data were in good agreement with those reported from Keshtkar and Ashbaugh (2007) who studied PAHs emissions from rice straw burning in California, and Lemieux et al. (2004). Among the studied PAHs, fluoranthene and benz(a)anthracene were the most abundant. Viana et al. (2008) found similar results when measuring PAHs concentration from open burning of rice straw residues. The predominance of volatile PAH compounds with three- and four-rings in rice straw smoke agrees with the results in Keshtkar and Ashbaugh (2007) from rice, Oanh et al. (1999) from wood and Venkataraman et al. (2002) from biofuels combustion. According to Khan et al. (2009), in incomplete combustion, the fragments of the mainly aromatic structure of the fuel are emitted and escape unburned to the atmosphere. However, Lu et al. (2009) and Korenaga et al. (2001) investigated that water in the rice straw had a depression effect on PAHs emission, with lowest emissions recorded from samples containing the highest moisture content. Conde et al. (2005) identified not only the type of fuel (burned crop residue), but also the type of device used for burning, as the main factors influencing the combustion process and thus the concentration of PAHs produced. 
Overall, EFs of atmospheric pollutants measured in our study $\left(\mathrm{CO}_{2}\right.$ and the organic and inorganic constituents of released PM) were higher in the $20 \%$ moisture content. This difference could be attributed to the incomplete combustion at higher levels of rice straw moisture content.

\subsection{Emission ratios and modified combustion efficiency}

According to Andreae and Merlet (2001) flaming derived species correlate well with $\mathrm{CO}_{2}$. Consequently, other gaseous pollutants could be estimated through the emission ratio of a gas relative to $\mathrm{CO}_{2}$. Results of $\mathrm{CO}, \mathrm{SO}_{2}, \mathrm{NO}_{2}$, and $\mathrm{NO}$ emitted during the burning of rice at different moisture contents and stages are shown in Table 4. Emission factors of $\mathrm{CO}, \mathrm{SO}_{2}, \mathrm{NO}_{2}$, and $\mathrm{NO}$ were obtained using ER relative to $\mathrm{CO}_{2}$. The concentrations of these gases, measured by detection tubes, were used to estimate the emissions of these pollutants (Lemieux et al., 2004). For all gaseous pollutants, results showed higher emissions during the flaming stage. These results are in accordance with Lobert et al. (1991) except for CO emissions. These authors obtained maximum $\mathrm{CO}$ emissions during the smoldering stage, in contrast with the results obtained in our study. Fuel moisture content is one of the main factors affecting burning stages (Lobert et al., 1991).

Average $\mathrm{SO}_{2}$ and $\mathrm{NO}$ emissions decreased with moisture content. In contrast, $\mathrm{CO}$ and $\mathrm{NO}_{2}$ emissions increased with moisture content, except for $\mathrm{NO}_{2}$ during the flaming stage. Several authors documented that when $\mathrm{CO}$ level in smoke increases during pyrolysis processes the amount of PAHs also increases (Gulyurtlu et al., 2003, Khalfi et al., 2000). Our results showed that PAHs emissions also increased with the moisture content. Carbon monoxide and PAHs are typically produced by incomplete combustion processes and are closely related to the atmosphere where the combustion takes place (Conde et al., 2005).

Modified combustion efficiency was $98.1,94.9$ and $93.6 \%$ for 5, 10, and 20\% moisture content, respectively. Higher MCE values were obtained in tests with lower moisture content.

Despite there have been calls for improvements in harvesting technologies and residue management systems to avoid straw burning (Brye et al., 2006, Gupta et al., 2004, YadvinderSingh et al., 2004), this practice is still common in many areas. Our results provide knowledge on straw conditions, particularly moisture content, affecting pollutant emissions. According to our results, rice straw burning should be done after straw drying and under minimal moisture conditions to lower pollutant emission levels. Nevertheless, further studies are required to improve rice straw management. Appropriate off-site uses of this straw should be investigated and implemented in practice to avoid open-field burning.

\section{Conclusions}

This study was designed to evaluate the effect of rice straw moisture content $(5 \%, 10 \%$, and 20\%) on $\mathrm{CO}_{2}, \mathrm{PM}, \mathrm{CO}, \mathrm{NOx}, \mathrm{SO}_{2}$, dioxins, heavy metals, and PAHs during rice straw burning. Overall, EFs of atmospheric pollutants measured in our study $\left(\mathrm{CO}_{2}\right.$ and on organic and inorganic 
constituents of released PM) were higher in the $20 \%$ moisture content. This difference could be attributed to the incomplete combustion at higher levels of rice straw moisture content. The following conclusions can be drawn from this study:

Burning duration was significantly longer in $20 \%$ moisture treatment $(\mathrm{P}<0.05)$ compared with the rest. This was mainly attributable to the flaming stage, which was about two-fold longer in $20 \%$ moisture treatment compared other treatments. The amount of burned straw and ashes decreased with increasing moisture content $(\mathrm{P}<0.001)$.

The main product obtained during the combustion process was $\mathrm{CO}_{2}$, with emission values ranging from 692 (10\% moisture content) to $835 \mathrm{~g} \mathrm{CO}_{2} \mathrm{~kg}$ dry straw $^{-1}$ (20\% moisture content). Average emissions of $\mathrm{CO}_{2}$ were similar $(\mathrm{P}>0.05)$ among moisture treatments.

Emission factors for PM (PM2.5, PM10-2.5, and TSP) were significantly higher in the 20\% moisture treatment $(\mathrm{P}<0.005)$ compared with the rest of treatments. The PM2.5 fraction accounted to more than $60 \%$ of total PM mass.

Emission factors for dioxins increased with straw moisture, being the highest in $20 \%$ moisture treatment, although showing a wide variability among burning tests $(\mathrm{P}>0.05)$.

Emissions factors for heavy metals were low and similar among moisture treatments $(\mathrm{P}>0.05)$. Emission factors for individual PAHs were generally higher in $20 \%$ moisture content with differences among individual PAHs. The sum of EFs of nine PAHs was $3.02 \mu \mathrm{g} \mathrm{kg}^{-1}$ (5\% moisture content), $8.32 \mu \mathrm{g} / \mathrm{kg}(10 \%$ moisture content) and $17.1 \mu \mathrm{g} / \mathrm{kg}$ (20\% moisture content).

Emission factors of $\mathrm{CO}, \mathrm{SO}_{2}, \mathrm{NO}_{2}$ and $\mathrm{NO}$ were obtained using ER relative to $\mathrm{CO}_{2}$. These results showed higher emissions during the flaming stage. Average $\mathrm{SO}_{2}$ and $\mathrm{NO}$ emissions decreased with moisture content. In contrast, $\mathrm{CO}$ emissions increased with the moisture content.

According to our results, rice straw burning should be done after straw drying and under minimal moisture conditions to lower pollutant emission levels. Nevertheless, further studies are required to improve rice straw management. Appropriate off-site uses of this straw should be investigated and implemented in practice to avoid open-field burning.

\section{Acknowledgments}

Authors thank Ignacio Iturriaga and Eduardo Loma, members of the Fire Brigade of Valencia, for providing support during rice straw burning tests. This study was financially supported by the Vicerrectorado de Investigación of the UPV (Programa de Apoyo a la Investigación y Desarrollo, PAID-06-11 Program, Project No. 1950).

\section{References}


Andreae, M. O., Merlet, P., 2001. Emission of trace gases and aerosols from biomass burning. Global Biogeochemical Cycles. 15, 955-966.

AOAC International., 2003. Official methods of analysis of AOAC international. Official Method 945.18. Cereals Adjuncts, 17th ed. 2nd revision. Association of Analytical Communities, Gaithersburg, MD, USA.

Arai, T., Takaya, T., Ito, Y., Hayakawa, K., Tshima, S., Shibuya, C., Nomura, M., Yoshimi, N., Shibayama, M., Yasuda, Y., 1998. Bronchial asthma induced by rice. Internal Medicine. 37, 98101.

ASHRAE., 2001. ASHRAE Fundamentals Handbook - Printed edition.

ASTM., 2000. Standard Test Method for Gross Calorific Value of Coal and Coke by the Adiabatic Bomb Calorimeter. Designation D2015-00.

Brye, K.R., Longer, D.E., Gbur, E.E., 2006. Impact of tillage and residue burning on carbon dioxide flux in a wheatesoybean production system. Soil Science Society of America Journal 70, $1145-1154$.

Cao, G., Zhang, X., Wang, Y., Zheng, F., 2008. Estimation of emissions from field burning of crop straw in China. Chinese Science Bulletin. 53, 784-790.

CEN., 1998. CEN-EN 12341: Air quality. Determination of the PM10 fraction of suspended particulate matter. Reference method and field test procedure to demonstrate reference equivalence of measurement methods.

Cheng, M., Horng, C., Su, Y., Lin, L., Lin, Y., Chou, C., 2009. Particulate matter characteristics during agricultural waste burning in Taichung City, Taiwan. Journal of Hazardous Materials. 165, 187-192.

Conde, F. J., Ayala, J. H., Afonso, A. M., González, V., 2005. Emissions of polycyclic aromatic hydrocarbons from combustion of agricultural and sylvicultural debris. Atmospheric environment. $39,6654-6663$.

Dhammapala, R., Claiborn, C., Jimenez, J., Corkill, J., Gullet, B., Simpson, C., Paulsen, M., 2007. Emission factors of PAHs, methoxyphenols, levoglucosan, elemental carbon and organic carbon from simulated wheat and Kentucky bluegrass stubble burns. Atmospheric environment. 41, 26602669.

Estellés, F., Calvet, S., Ogink, N. W. M., 2010. Effects of diurnal emission patterns and sampling frequency on precision of measurement methods for daily ammonia emissions from animal houses. Biosystems Engineering. 107, 16-24. 
Gadde, B., Bonnet, S., Menke, C., Garivait, S., 2009. Air pollutant emissions from rice straw open field burning in India, Thailand and the Philippines. Environmental Pollution. 157, 1554-1558.

Gullett, B. K., Touati, A., 2003. PCDD/F emissions from burning wheat and rice field residue. Atmospheric environment. 37, 4893-4899.

Gulyurtlu, I., Karunaratne, D. G. G. P., Cabrita, I., 2003. The study of the effect of operating parameters on the PAH formation during the combustion of coconut shell in a fluidised bed. Fuel. $82,215-223$.

Gupta, P.K., Sahai, S., Singh, N., Dixit, C.K., Singh, D.P., Sharma, C., Tiwari, M.K., Gupta, R.K., Garg, S.C., 2004. Residue burning in rice-wheat cropping system: causes and implications. Research Communications, Current Science 87 (12), 1713-1717.

Hays, M. D., Fine, P. M., Geron, C. D., Kleeman, M. J., Gullett, B. K., 2005. Open burning of agricultural biomass: Physical and chemical properties of particle-phase emissions. Atmospheric environment. 39, 6747-6764.

He, G., Tsutsumi, T., Zhao, B., Baston, D. S., Zhao, J., Heath-Pagliuso, S., Denison, M. S., 2011. Third-Generation Ah Receptor-Responsive Luciferase Reporter Plasmids: Amplification of DioxinResponsive Elements Dramatically Increases CALUX Bioassay Sensitivity and Rensponsiveness. Toxicological Sciences. 123, 511-522.

Kadam, K. L., Forrest, L. H., Jacobson, W. A., 2000. Rice straw as a lignocellulosic resource: collection, processing, transportation, and environmental aspects. Biomass and Bioenergy. 18, 369389.

Keshtkar, H., Ashbaugh, L., 2007. Size distribution of polycyclic aromatic hydrocarbon particulate emission factors from agricultural burning. Atmospheric environment. 41, 2729-2739.

Khalfi, A., Trouvé, G., Delobel, R., Delfosse, L., 2000. Correlation of CO and PAH emissions during laboratory-scale incineration of wood waste furnitures. Journal of Analytical and Applied Pyrolysis. 56, 243-262.

Khan, A. A., Jong, W., Jansens, P. J., Spliethoff, H., 2009. Biomass combustion in fluidized bed boilers: Potential problems and remedies. Fuel processing technology. 90, 21-50.

Korenaga, T., Liu, X., Huang, Z., 2001. The infuence of moisture content on polycyclic aromatic hydrocarbons emission during rice straw burning. Chemosphere: Global Change Science. 3, 117 122.

Lemieux, P. M., Lutes, C. C., Santoianni, D. A., 2004. Emissions of organic air toxics from open burning: a comprehensive review. Progress in Energy and Combustion Science. 30, 1-32. 
Lin, L. F., Lee, W. J., Li, H. W., Wang, M. S., Chang-Chien, G. P., 2007. Characterization and inventory of $\mathrm{PCDD} / \mathrm{F}$ emissions from coal-fired power plants and other sources in Taiwan. Chemosphere. 68, 1642-1649.

Lobert, J. M., Scharffe, D. H., Hao, W. M., Kuhlbusch, T. A., Seuwen, R., Warneck, P., Crutzen, P. J., 1991. Experimental evaluation of biomass burning emissions: Nitrogen and Carbon containing compounds. 289-304.

Lu, H., Zhu, L., Zhu, N., 2009. Polycyclic aromatic hydrocarbon emission from straw burning and the influence of combustion parameters. Atmospheric environment. 43, 978-983.

Minomo, K., Ohtsuka, N., Nojiri, K., Hosono, S., Kawamura, K., 2011. Polychlorinated dibenzo-pdioxins, dibenzofurans, and dioxin-like polychlorinated biphenyls in rice straw smoke and their origins in Japan. Chemosphere. 84, 950-956.

Miura, Y., Kanno, T., 1997. Emissions of trace gases $\left(\mathrm{CO}_{2}, \mathrm{CO}, \mathrm{CH}_{4}\right.$ and $\left.\mathrm{N}_{2} \mathrm{O}\right)$ resulting from rice straw burning. Soil Science \& Plant Nutrition. 43, 849-854.

Oanh, N. T. K., Reutergardh, L. B., Dung, N. T., 1999. Emission of polycyclic aromatic hydrocarbons and particulate matter from domestic combustion of selected fuels. Environmental Sciecne Technology. 33, 2703-2709.

Ogawa, M., Yoshida, N., 2005. Nitrous oxide emission from the burning of agricultural residue. Atmospheric environment. 39, 3421-3429.

Ortiz de Zárate, I., Ezcurra, A., Lacaux, J. P., Vhan Dhin, P., 2000. Emission factor estimates of cereal waste burning in Spain. Atmospheric environment. 3183-3193.

Sahai, S., Sharma, C., Singh, D. P., Dixit, C. K., Singh, N., Sharma, P., Singh, K., Bhatt, S., Ghude, S., Gupta, V., Gupta, R. J., Tiwari, M. K., Garg, S. C., Mitra, A. P., Gupta, P. K., 2007. A study for development of emission factors for trace gases and carbonaceous particulate species from in situ burning of wheat straw in agricultural fields in India. Atmospheric Environment. 41, 9173-9183.

SAS, 2009. SAS User's Guide: Statistics (Release 9.1). SAS_Institute Inc., Cary, NC.

Sanchis, E., Ferrer, M., Torres, A. G., Cambra-López, M., Calvet, S., 2012. Effect of water and straw management practices on methane emissions from rice fields: A review through a metaanalysis. Environmental Engineering Science. 29, 1053-1062.

Shih, S. I., Lee, W. J., Lin, L. F., Huang, J. Y., Su, J. W., Chang-Chien, G. P., 2008. Significance of biomass open burning on the levels of polychlorinated dibenzo-p-dioxins and dibenzofurans in the ambient air. Journal of Hazardous Materials. 153, 276-284. 
Torigoe, K., Hasegawa, S., Numata, O., Yazaki, S., Matsumaga, M., Boku, N., Hiura, M., Ino, H., 2000. Influence of emission from rice straw burning on bronchial asthma in children. Pediatrics International. 42, 143-150.

Venkataraman, C., Negi, G., Sardar, S. B., Rastogi, R., 2002. Size distributions of polycyclic aromatic hydrocarbons in aerosol emissions from biofuel combustion. Aerosol Science. 33, 503518.

Viana, M., López, J. M., Querol, X., Alastuey, A., García-Gacio, D., Blanco-Heras, G., LópezMahía, P., Piñeiro-Iglesias, M., Sanz, M. J., Sanz, F., Chi, X., Maenhaut, W., 2008. Tracers and impact of open burning rice straw residues on PM in Eastern Spain. Atmospheric environment. 42, 1941-1957.

Ward, D. E., Sussot, R. A., Kauffman, J. B., Babbitt, R. E., Cummings, D. L., Dias, B., Holben, B. N., Kaufman, Y. J., Rasmussen, R. A., Setzer, A. W., 1992. Smoke and fire characteristics for Cerrado and deforestation burns is Brazil: BASE-B experiment. Journal of Geophysical Research. 97, 14601-14619.

Yadvinder-Singh, Bijay-Singh, Ladha, J.K., Khind, C.S., Khera, T.S., Bueno, C.S., 2004. Effect of residue decomposition on productivity and soil fertility in rice-wheat rotation. Soil Science Society of America Journal 68, 854-864.

Zhang, H., Ye, X., Cheng, T., Chen, J., Yang, X., Wang, L., Zhang, L., 2008. A laboratory study of agricultural crop residue combustion in China: Emission factors and emission inventory. Atmospheric environment. 42, 8432-8441.

Zhang, J., Smith, K. R., Ma, Y., Ye, S., Jiang, F., Qi, W., Liu, P., Khalil, M. A. K., Rasmussen, R. A., Thorneloe, S. A., 2000. Greenhouse gases and other airborne pollutants from household stoves in China: a database for emission factors. Atmospheric environment. 34, 4537-4549. 
Table 1. Physical-chemical composition of initial rice straw used in this study, on dry matter (d.m.) basis.

\begin{tabular}{|c|c|}
\hline Moisture (\%) & 5.67 \\
\hline Ash (\%) & 13.74 \\
\hline Heating value (MJ kg d.m. ${ }^{-1}$ ) & 16.33 \\
\hline $\mathrm{C}(\%$ d.m. $)$ & 38.21 \\
\hline $\mathrm{N}(\%$ d.m. $)$ & 0.53 \\
\hline Dioxins (pg TEQ $\mathrm{g}^{-1}$ ) & 0.50 \\
\hline $\mathrm{Pb}\left(\mu \mathrm{g} \mathrm{kg}^{-1}\right)$ & 356.8 \\
\hline $\mathrm{Cd}\left(\mu \mathrm{g} \mathrm{kg}^{-1}\right)$ & 20.6 \\
\hline As $\left(\mu \mathrm{g} \mathrm{kg}^{-1}\right)$ & 543.3 \\
\hline $\mathrm{Ni}\left(\mu \mathrm{g} \mathrm{kg}^{-1}\right)$ & 3833 \\
\hline PAHs $\left(\mu \mathrm{g} \mathrm{kg}^{-1}\right)$ & $<\mathrm{QL}$ \\
\hline $\begin{array}{l}\text { QL: Quantification limit } \\
\text { Quantification limits in straw san } \\
6.25 \mu \mathrm{g} \mathrm{kg}^{-1} ; \mathrm{Cd}: 0.5 \mu \mathrm{g} \mathrm{kg}^{-1} ; \mathrm{Pb} \text { : } \\
\mu \mathrm{g} \mathrm{kg}^{-1}\end{array}$ & $\begin{array}{l}\text { TEQ g-1; PAHs: } \\
\operatorname{lg~kg}^{-1} ; \text { Ni: } 0.5\end{array}$ \\
\hline
\end{tabular}


Table 2. Combustion characteristics of each straw burning test (average \pm standard deviation), $\mathrm{n}=4$.

\begin{tabular}{ccccc}
\hline \multicolumn{2}{c}{ Straw moisture content } & $5 \%$ & $10 \%$ & $20 \%$ \\
\hline \multirow{2}{*}{ Duration (min) } & Flaming & $9.5 \pm 1.5^{\mathrm{a}}$ & $11.8 \pm 1.5^{\mathrm{a}}$ & $23.0+0.9^{\mathrm{a}}$ \\
& Smoldering & $9.5 \pm 2.2^{\mathrm{a}}$ & $13.0 \pm 2.3^{\mathrm{a}}$ & $10.8 \pm 2.4^{\mathrm{a}}$ \\
& Total & $19.0 \pm 3.4^{\mathrm{a}}$ & $24.8 \pm 3.4^{\mathrm{a}}$ & $33.8 \pm 4.7^{\mathrm{b}}$ \\
\hline \multirow{2}{*}{ Burning partition } & Burned straw & $2.19 \pm 0.04^{\mathrm{a}}$ & $1.96 \pm 0.22^{\mathrm{a}}$ & $1.15 \pm 0.20^{\mathrm{b}}$ \\
$(\mathrm{kg})$ & Unburned straw & $0.31 \pm 0.02^{\mathrm{a}}$ & $0.39 \pm 0.18^{\mathrm{a}}$ & $0.77 \pm 0.09^{\mathrm{b}}$ \\
& Ash & $0.360 \pm 0.003^{\mathrm{a}}$ & $0.340 \pm 0.006^{\mathrm{b}}$ & $0.278 \pm 0.017^{\mathrm{c}}$ \\
\hline
\end{tabular}

a,b,c: Significant differences at $\mathrm{P}<0.05$ 
Table 3. Average emission factors and standard deviation of $\mathrm{CO}_{2}, \mathrm{PM}$, particle-bound PAHs, particlebound dioxins and particle-bound heavy metals ( $\mathrm{n}=4$, except for particle-bound PAHs, particle-bound dioxins and particle-bound heavy metals where $n=2$ ) expressed per kg of dry straw.

\begin{tabular}{|c|c|c|c|c|}
\hline \multicolumn{2}{|c|}{ Straw moisture content } & $5 \%$ & $10 \%$ & $20 \%$ \\
\hline \multicolumn{2}{|l|}{$\mathrm{CO}_{2}\left(\mathrm{~g} \mathrm{~kg}^{-1}\right)$} & $776 \pm 21^{\mathrm{a}}$ & $692 \pm 28^{\mathrm{a}}$ & $835 \pm 136^{\mathrm{a}}$ \\
\hline \multirow{3}{*}{$\begin{array}{l}\text { Particulate matter } \\
\left(\mathrm{g} \mathrm{kg}^{-1}\right)\end{array}$} & PM2.5 & $5.86 \pm 1.85^{\mathrm{a}}$ & $8.66 \pm 2.29^{\mathrm{a}}$ & $20.67 \pm 3.88^{b}$ \\
\hline & PM10-2.5 & $5.56 \pm 1.71^{\mathrm{a}}$ & $8.90 \pm 2.39^{\mathrm{a}}$ & $20.17 \pm 4.43^{\mathrm{b}}$ \\
\hline & TSP & $8.41 \pm 4.52^{\mathrm{a}}$ & $14.26 \pm 3.23^{\mathrm{a}}$ & $31.09 \pm 11.79^{b}$ \\
\hline \multicolumn{2}{|l|}{ Dioxins (pg TEQ $\mathrm{kg}^{-1}$ ) } & $87 \pm 41^{\mathrm{a}}$ & $142 \pm 3^{\mathrm{a}}$ & $156 \pm 47^{\mathrm{a}}$ \\
\hline \multirow{4}{*}{$\begin{array}{l}\text { Heavy metals } \\
\left(\mu \mathrm{g} \mathrm{kg}^{-1}\right)\end{array}$} & $\mathrm{Cd}$ & $0.11 \pm 0.001^{\mathrm{a}}$ & $0.10 \pm 0.023^{\mathrm{a}}$ & $0.12 \pm 0.035^{\mathrm{a}}$ \\
\hline & $\mathrm{Pb}$ & $<\mathrm{QL}$ & $<Q L$ & $<Q L$ \\
\hline & As & $0.94 \pm 0.15^{\mathrm{a}}$ & $0.86 \pm 0.09^{\mathrm{a}}$ & $1.22 \pm 0.18^{\mathrm{a}}$ \\
\hline & $\mathrm{Ni}$ & $<\mathrm{QL}$ & $<\mathrm{QL}$ & $<\mathrm{QL}$ \\
\hline \multirow{9}{*}{$\begin{array}{l}\text { PAHs } \\
\left(\mathrm{ng} \mathrm{kg}^{-1}\right)\end{array}$} & Fla & $1086 \pm 242^{\mathrm{a}}$ & $3428 \pm 1,793^{\mathrm{a}}$ & $6925 \pm 266^{b}$ \\
\hline & $\mathrm{B}(\mathrm{a}) \mathrm{A}$ & $838 \pm 278^{\mathrm{a}}$ & $2195 \pm 1,117^{\mathrm{ab}}$ & $4145 \pm 347^{b}$ \\
\hline & $\mathrm{B}(\mathrm{b}) \mathrm{F}$ & $209 \pm 73^{\mathrm{a}}$ & $598 \pm 257^{\mathrm{ab}}$ & $1130 \pm 176^{\mathrm{b}}$ \\
\hline & $B(j) F$ & $85 \pm 27^{\mathrm{a}}$ & $250 \pm 114^{\mathrm{a}}$ & $515 \pm 81^{b}$ \\
\hline & $\mathrm{B}(\mathrm{k}) \mathrm{F}$ & $92 \pm 28^{\mathrm{a}}$ & $264 \pm 109^{\mathrm{ab}}$ & $506 \pm 82^{b}$ \\
\hline & $\mathrm{B}(\mathrm{a}) \mathrm{P}$ & $351 \pm 122^{\mathrm{a}}$ & $1,040 \pm 497^{\mathrm{ab}}$ & $1851 \pm 277^{\mathrm{b}}$ \\
\hline & $\mathrm{I}(1,2,3-\mathrm{c}, \mathrm{d}) \mathrm{P}$ & $200 \pm 57^{\mathrm{a}}$ & $64 \pm 405^{\mathrm{a}}$ & $1152 \pm 189^{\mathrm{a}}$ \\
\hline & $\mathrm{D}(\mathrm{a}, \mathrm{h}) \mathrm{A}$ & $51 \pm 15^{\mathrm{a}}$ & $134 \pm 80^{\mathrm{a}}$ & $255 \pm 46^{\mathrm{a}}$ \\
\hline & $\mathrm{B}(\mathrm{g}, \mathrm{h}, \mathrm{i}) \mathrm{Pe}$ & $106 \pm 33^{\mathrm{a}}$ & $346 \pm 169^{a}$ & $627 \pm 133^{\mathrm{a}}$ \\
\hline
\end{tabular}

a,b: Significant differences at $\mathrm{P}<0.05$

QL: Quantification limit

Abbreviations: Fla: Fluoranthene; B(a)A: benz(a)anthracene; B(b)F: benz(b)fluoranthene; B(j)F:

benz(j)fluoranthene; B(k)F: benz(k)fluoranthene; B(a)P: benz(a)pyrene; I(1,2,3-c,d)P: indene $(1,2,3$ -

c,d)pyrene; D(a,h)A: dibenz(a,h)antracene; B(g,h,i)Pe: benz(g,h,i)perylene

Quantification limits in PM10 samples: Dioxins: 1.006 pg TEQ kg ${ }^{-1}$; PAHs: $50 \mathrm{ng} \mathrm{kg}^{-1}$; Cd: $0.07 \mu \mathrm{g} \mathrm{kg}^{-1}$;

$\mathrm{Pb}: 1 \mu \mathrm{g} \mathrm{kg}^{-1}$; As: $0.5 \mu \mathrm{g} \mathrm{kg}^{-1}$; Ni: $3 \mu \mathrm{g} \mathrm{kg}^{-1}$ 
Table 4. Average emissions of $\mathrm{CO}, \mathrm{SO}_{2}, \mathrm{NO}_{2}$ and $\mathrm{NO}\left(\mathrm{g} \mathrm{kg}\right.$ dry straw $\left.{ }^{-1}\right)$ depending on straw moisture content and combustion stage. Ranges in brackets.

\begin{tabular}{ccccc}
\hline \multicolumn{2}{c}{ Straw moisture content } & $5 \%$ & $10 \%$ & $20 \%$ \\
\hline \multirow{2}{*}{$\mathrm{CO}$} & Flaming & $19.3(6.6-28.8)$ & $65.4(16.2-139)$ & $82.6(11.1-185)$ \\
& Smoldering & $11.3(4.0-23.5)$ & $12.4(5.6-22.4)$ & $37.3(29.9-47.1)$ \\
\hline \multirow{2}{*}{$\mathrm{SO}_{2}$} & Flaming & $7.5(0.5-27.1)$ & $1.8(0.5-2.4)$ & $0.9(0-1.3)$ \\
& Smoldering & $0.2(0-0.5)$ & $0.2(0-0.4)$ & $0.4(0-1.6)$ \\
\hline \multirow{2}{*}{$\mathrm{NO}_{2}$} & Flaming & $1.6(0-4.2)$ & $7.3(0-26.1)$ & $3.2(0-6.0)$ \\
& Smoldering & $0.4(0-0.9)$ & $2.1(0-5.4)$ & $3.5(0-6.6)$ \\
\hline \multirow{2}{*}{$\mathrm{NO}$} & Flaming & $48.0(10.5-105)$ & $40.9(6.7-136)$ & $28.0(9.5-55.2)$ \\
& Smoldering & $3.8(0-7.8)$ & $9.8(0-27.9)$ & $10.9(0-17.2)$ \\
\hline
\end{tabular}




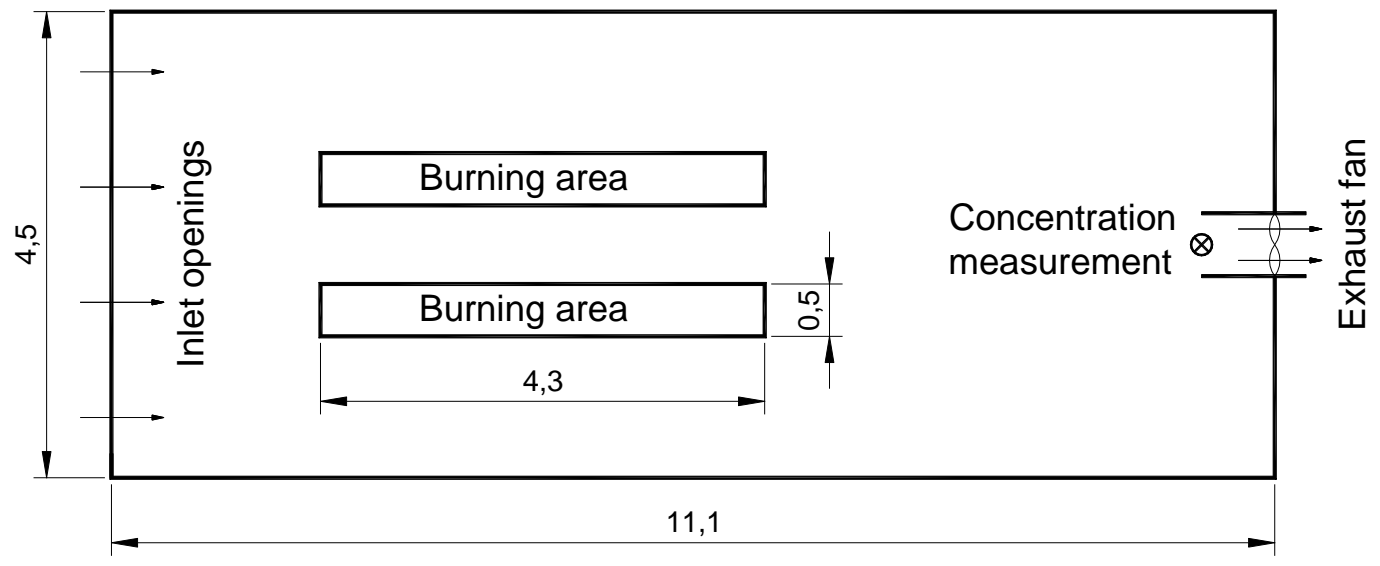

Fig. 1. Distribution of burning areas, air inlets and outlets, and concentration measurements in the environmentally controlled chamber. Dimensions in meters. 

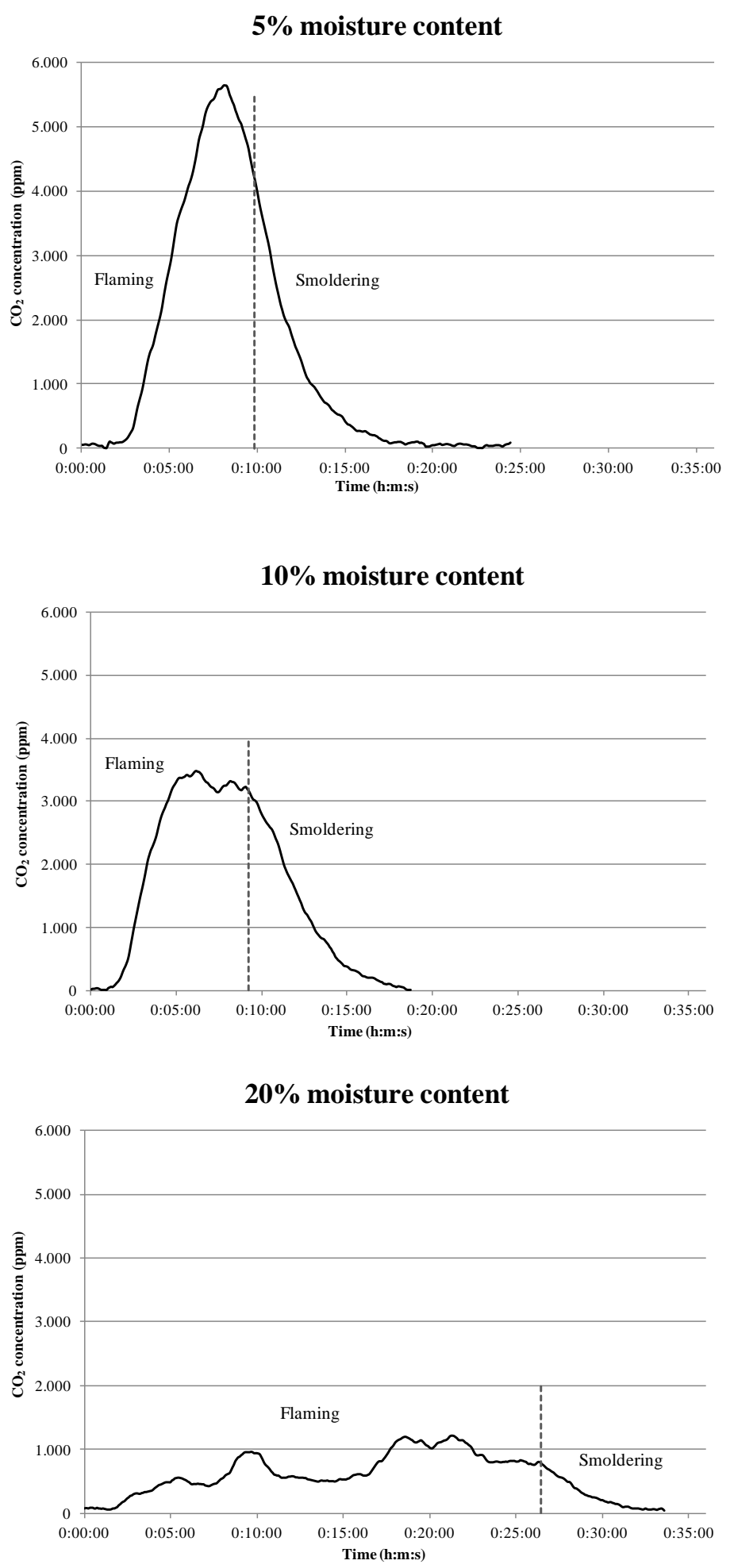

Fig. 2. Evolution of $\mathrm{CO}_{2}$ concentration in burning tests using straw with different moisture contents. 